University of Nebraska - Lincoln

DigitalCommons@University of Nebraska - Lincoln

Roman L. Hruska U.S. Meat Animal Research

U.S. Department of Agriculture: Agricultural Center

Research Service, Lincoln, Nebraska

1988

\title{
Yield Grades and Cutability of Carcass Beef With and Without Kidney and Pelvic Fat
}

John D. Crouse

U.S. Meat Animal Research Center

Robert M. Koch

U.S. Meat Animal Research Center

Michael E. Dikeman

Kansas State University

Follow this and additional works at: https://digitalcommons.unl.edu/hruskareports

Part of the Animal Sciences Commons

Crouse, John D.; Koch, Robert M.; and Dikeman, Michael E., "Yield Grades and Cutability of Carcass Beef With and Without Kidney and Pelvic Fat" (1988). Roman L. Hruska U.S. Meat Animal Research Center. 108.

https://digitalcommons.unl.edu/hruskareports/108

This Article is brought to you for free and open access by the U.S. Department of Agriculture: Agricultural Research Service, Lincoln, Nebraska at DigitalCommons@University of Nebraska - Lincoln. It has been accepted for inclusion in Roman L. Hruska U.S. Meat Animal Research Center by an authorized administrator of DigitalCommons@University of Nebraska - Lincoln. 


\title{
Yield Grades and Cutability of Carcass Beef With and Without Kidney and Pelvic Fat
}

\author{
John D. Crouse, Robert M. Koch, and Michael E. Dikeman ${ }^{1,2}$
}

\section{Introduction}

The Agricultural Marketing Service proposed a revision to the yield grade standards to provide the industry with an option regarding the retention or removal of kidney and pelvic fat (KPF) depending on market requirements. The proposal was subsequently withdrawn. The present yield grades are determined by consideration of external fat thickness, hot carcass wt, ribeye area, and estimated percent KPF. The proposed revision would eliminate consideration of KPF in the determination of yield grades.

The present study used 2,550 observations of retail yield of carcasses obtained from steers with genetically diverse growth rates and fattening characteristics to: 1) examine by yield grade the frequency, mean yield grade, and mean cutability for the present USDA 1980 equation, the present USDA 1980 equation omitting KPF, and the proposed newly developed equation (USDA 1984); and 2) compare precision of the USDA 1980 equation and the proposed equation (USDA 1984) for estimating yield.

\section{Procedure}

Carcass sides from $F_{1}$ steers from the MARC Germ Plasm Evaluation Program were grouped as British (Angus, Hereford, Red Poll, or South Devon; $n=934$ ), Continental (Charolais, Limousin, Chianina, Brown Swiss, Simmental, Gelbvieh, Maine Anjou, Pinzgauer, or Tarentaise; $n=1,214)$, Zebu (Brahman or Sahiwal; $n=269$ ), or Jersey $(n=133)$ sire breeds with Hereford or Angus dams. Steers were fed ad libitum on a corn silage and concentrate diet that averaged 2.8 Mcal metabolizable energy/kg dry matter over the finishing period. Each year steers were slaughtered at one of three to five slaughter dates that ranged from 190 to 300 days postweaning.

Yield grade $(Y)$ classifications for carcasses were determined by three equations: 1) the four-variable equation $\left(\mathrm{Y}_{\mathrm{a}}\right)$ on which the present standards are based $($ USDA 1980$)=2.5+2.50$ adjusted fat thickness (AFT), in +.0035 hot carcass wt $(\mathrm{HCW}), \mathrm{Ib}-.32$ ribeye area (REA), in ${ }^{2}+.2 \%$ kidney, pelvic, and heart fat (KPF); 2) $\mathrm{Y}_{\mathrm{b}}=$ present equation with intercept changed to 3.2 and KPF coefficient omitted; and 3) $Y_{c}$ (proposed; USDA $1984)=3.0+2.50 \mathrm{AFT}+.00186 \mathrm{HCW}-.202$ REA. Frequency distribution of carcasses within yield grades by each prediction equation was determined over all breed crosses and within each breed-cross grouping.

\section{Results}

Frequency, mean yield grade, and mean cutability for each estimating equation ( $\mathrm{a}$ through $\mathrm{c}$ ) by yield grade are given in Table 1. Average cutability of carcasses was 2 percentage points (44.9 vs 46.9 ) greater when KPF was omitted. Mean cutability within yield grade 1 was .7 of a percentage point greater for equation $\mathrm{Y}_{\mathrm{C}}$ than for equation $Y_{b}$. Within yield grade 5 , however, mean cutability was 1.0 percentage point less for equation $Y_{c}$ than for equation $Y_{b}$. Only .1 of a percentage point difference in cutability was observed between equations $Y_{c}$ and $Y_{b}$ within yield grade 2 . Therefore, cutability percentages of carcasses classified by equation $Y_{C}$ tend to be greater in yield grades 1 and 2 and are less in yield grades 3,4 , and 5 as compared with equation $Y_{\mathrm{b}}$.

Variation in cutability (SD) was similar among yield grade classes within equations, as well as among the three equations.

Frequency distribution of carcasses within yield grade scores differed among the three estimating equations (Table 1). Percentage of carcasses within yield grade 3 remained about the same among the three equations. However, increases in percentage of carcasses with yield grade 2 were observed for equations $Y_{b}$ and $Y_{c}$ (30.1 vs 37.7 and $43.4 \%$ ). Equation $Y_{c}$ produced a greater shift of carcasses into yield grade 2 than did equation $Y_{b}$. A shift in percentage carcasses from yield grade 1 to yield grade 2 was observed for equation $Y_{C}$. USDA (1984) evaluated the potential shift on a population of 5,846 carcasses. The proposed equation $Y_{c}$ increased the frequency of carcasses within yield grade 3 by 10.5 percentage points, and there was a concomitant decrease in the number of carcasses in yield grades $1,2,4$, and 5 .

Correlations (not tabulated) between cutability (C) and yield grades indicate that estimative equations $Y_{a}$ and $Y_{c}$ were about equal in accounting for variation in percentage cutability, but equation $Y_{b}$ accounted for slightly less variation. The correlations and standard deviations of cutability from regressions were: .825 and $1.47 \%$ for $\mathrm{C}_{\mathrm{a}}$ on $\mathrm{Y}_{\mathrm{a}} ; .795$ and $1.53 \%$ for $\mathrm{C}_{\mathrm{b}}$ on $\mathrm{Y}_{\mathrm{b}}$; and .818 and $1.45 \%$ for $C_{c}$ on $Y_{c}$. The correlation between cutability without $\mathrm{KPF}$ and cutability with $\mathrm{KPF}\left(\mathrm{C}_{\mathrm{a}}\right.$ and $\left.\mathrm{C}_{\mathrm{c}}\right)$ was .982. Therefore, after removal of the avg effect of the $2 \%$ difference in cutability associated with KPF, the two methods $\left(Y_{a}\right.$ and $\left.Y_{c}\right)$ of computing cutability had similar accuracy as measures of yield; Therefore, changes in procedures for estimating yield of carcasses should be based on economic considerations.

'Crouse is the research leader, Meats Unit, MARC; Koch is a professor of animal science, University of Nebraska-Lincoln, stationed at MARC; Dikeman is a professor of animal science, Kansas State University, Manhattan.

${ }^{2}$ The full report of this work was published in J. Anim. Sci. 63:1134-1139. 
Table 1-Yield grade frequency $(F, \%)$, mean yield grade $(\bar{Y})$, and mean actual cutability $(\bar{C}, \%)$

\begin{tabular}{|c|c|c|c|c|c|c|c|c|c|c|c|c|}
\hline \multirow{3}{*}{$\begin{array}{l}\text { Yield } \\
\text { grade }\end{array}$} & \multicolumn{12}{|c|}{ Estimating equation ${ }^{a}$} \\
\hline & \multicolumn{4}{|c|}{ Equation a } & \multicolumn{4}{|c|}{ Equation b } & \multicolumn{4}{|c|}{ Equation c } \\
\hline & $\mathrm{F}$ & $\bar{Y}$ & $\overline{\mathrm{C}}$ & $S D^{b}$ & $\mathrm{~F}$ & $\overline{\mathrm{Y}}$ & $\overline{\mathbf{c}}$ & $\mathrm{SD}^{\mathrm{b}}$ & $\mathrm{F}$ & $\overline{\mathrm{Y}}$ & $\overline{\mathrm{C}}$ & $S D^{b}$ \\
\hline 1 & 6.3 & 1.65 & 48.7 & 1.6 & 5.3 & 1.72 & 50.4 & 1.6 & 2.3 & 1.81 & 51.1 & 1.5 \\
\hline 2 & 30.1 & 2.55 & 46.8 & 1.6 & 37.7 & 2.57 & 48.4 & 1.6 & 43.4 & 2.60 & 48.5 & 1.6 \\
\hline 3 & 46.2 & 3.44 & 44.3 & 1.7 & 45.2 & 3.42 & 46.1 & 1.7 & 47.5 & 3.39 & 45.7 & 1.7 \\
\hline 4 & 15.9 & 4.34 & 41.9 & 1.6 & 10.8 & 4.30 & 43.4 & 1.6 & 6.4 & 4.28 & 42.6 & 1.5 \\
\hline 5 & 1.5 & 5.32 & 39.2 & 1.7 & 1.0 & 5.33 & 40.5 & 1.6 & .4 & 5.32 & 39.5 & 1.2 \\
\hline Avg & & 3.23 & 44.9 & $2.6 \mathrm{c}$ & & 3.12 & 46.9 & $2.5^{\mathrm{c}}$ & & 3.08 & 46.9 & $2.5^{\mathrm{c}}$ \\
\hline
\end{tabular}

${ }^{a}$ Estimating equation $Y_{a}=$ USDA (1980); $Y_{b}=$ USDA (1980) with intercept adjusted to 3.2 and coefficient for KPF deleted; $Y_{c}=$ USDA (1984) proposal. oStandard deviation (SD) represents variation in cutability within a yield grade class.

cStandard deviation of individual observations about the overall mean. 